811.161.1'367:811.163.41'367

https://doi.org/10.18485/sj.2018.23.1.38

МАЈА 3. ВЕЈКОВИТ ${ }^{*}$

Универзитет у Нишу

Филозофски факултет
Оригинални научни рад

Примљен: 04. 01. 2018.

Прихваћен: 29. 01. 2018.

\title{
РУСКИ ОДРИЧНИ ЗАМЕНИЧКИ ПРИЛОЗИ \\ У ФУНКЦИЈИ ПРЕДИКАТА И ЮИХОВИ СРПСКИ ЕКВИВАЛЕНТИ ${ }^{* *}$
}

\begin{abstract}
У руском језику постоје безличне реченице чији се предикат изражава одричним заменичким прилозима (негде, некуда, некогда, незачем), најчешће у споју са инфинитивом (иако се инфинитив у неким случајевима може изоставити). Ове руске безличне реченице преводе се на српски језик безличним или двочланим реченицама у зависности од тога да ли је реченица проширена субјекатским детерминатором, тј. да ли реченица садржи у својој структури индиректни објекат којим се изражава вршилац радње. Предикат српских реченица најчешће се изражава одговарајућим безличним или личним обликом глагола немати у споју са прилозима за место, време, узрок. Ово и јесте предмет нашег истраживања чији су резултати представљени у овом раду.
\end{abstract}

Кључне речи: одрични заменички прилог, предикат, безличност, немати.

Руске безличне реченице са одричним заменичким речима у функцији предиката у славистичкој литератури имају различит статус: Маројевић их у својој Руској граматищи сврстава у безличне (в. Маројевић 2001²: 125,

${ }^{*}$ mveljkovic@mail.ru

** О овој теми усмено је реферисано на научном скупу „Наука и савремени универзитет 7” који је одржан 10. новембра 2017. године на Филозофском факултету у Нишу (в. Вељковић 2017 : 176-177). Рад у целости досад није публикован. 
130-131), код Скобљикове су разматране у оквиру инфинитивних ${ }^{1}$ реченица (в. Скобљикова 2006: 157-158), док се у Руској граматици РАН ове реченице одређују као „двокомпонентне” уз схему Pron ${ }_{\text {neg }}$ Inf (в. РГ2 2005: 346-348). Разлог за различито тумачење ових руских реченица свакако лежи у специфичности самих одричних заменичких речи са префиксом не- (в. Маројевић 2001': $180-181$, Колмакова 1999), а треба имати у виду и начин на који се изражава негација у руском језику, о чему је такође писано (в. Чурикова 2003).

Овим реченицама се, заправо, изражава посесивност у ширем смислу; на српски језик се ове руске безличне реченице преводе реченицама са одговарајућим обликом глагола немати у функцији предиката (в. Вељковић 2012, 2013).

У функцији предиката се у руским безличним реченицама могу наћи одричне заменичке речи са префиксом не- и то: 1) именичке заменице некого, нечего и 2) заменички прилози негде, некуда, неоткуда, некогда и незачем. Карактеристично за ове реченице је да у својој структури имају обавезан инфинитив (који може бити изостављен), али и да могу служити за изражавање периферне посесивности уколико су проширене субјекатским детерминатором израженим обликом датива (субјекат посесивности, тј. посесор). У српском језику овим руским безличним реченицама најчешће одговарају реченице са предикатом израженим личним или безличним обликом глагола немати, у зависности од тога да ли се реченицом изражава посесивност или не.

Предмет овог истраживања биле су само руске безличне реченице са одричним заменичким прилозима у функцији предиката и њихови српски еквиваленти. Грађа је ексцерпирана из романа Ф. М. Достојевског „Подросток” и његовог српског превода Милене и Радмила Маројевића².

Метод који смо у раду користили је конфронтациони; иако је истраживањем обухваћен роман у целини, релативно мали број примера (свега 17) био је пресудан да се одлучимо за квалитативни, а не за квантитативни вид анализе.

\section{a) негде}

У анализираном роману посведочено је свега три примера безличних реченица са одричним заменичким прилогом за место негде у функцији предиката.

\footnotetext{
${ }^{1}$ Бабајцева у Синтакси руског језика у фусноти на страници 229 упућује на литературу коју је корисно погледати у вези са разграничењем руских инфинитивних, безличних и безлично-инфинитивних реченица (Бабајцева 2015: 229).

${ }^{2}$ Потпуни библиографски подаци о коришћеним изворима налазе се на крају рада у делу Извори.
} 
Погледајмо пример руске безличне реченице у прошлом времену:

$\phi 1^{3}$

Правда, под надежду денег никто не давал, занять негде было, и пока терпели.

Дост Подр ч1 г1 VIII
Додуше, новац нико није давао на рачун тога, није се имало где позајмити и засад се трпело.

Дост Д1 25

У наведеном примеру је предикат у руској реченици изражен одричним заменичким прилогом негде и инфинитивом занять, а категорија времена се изражава безличним обликом копулативног глагола быть у прошлом времену (облик средњег рода было). Реченица није проширена субјекатским детерминатором јер се њоме не исказује значење поседовања, тако да у српском језику налазимо такође безличну реченицу са предикатом израженим одговарајућим безличним обликом перфекта глагола немати и заменички прилог где у функцији адвербијала за место; инфинитив је преведен такође инфинитивом (nозајмити). Уместо облика глагола немати (није се имало) у перфекту је могуће у одређеним ситуацијама употребити глагол бити у безличном облику (није било) што овде није случај. Постоји и могућност да се уместо инфинитива у преводу искористи конструкција $\partial a+$ презент (да се позајми).

Нормалан ред речи представљен је у следећем примеру:

$\phi 2$

Подписка перешла наконец на улицу, но негде было писать.
Уписивање се пренело најзад на улицу, али није се имало на чему писати.

У наведеном примеру је безлична реченица такође у прошлом времену. Глагол писать дозволио је преводиоцу да уместо прилога где као адвербијал за место у преводу употреби локатив са предлогом на чему. У руској реченици нема субјекатског детерминатора тако да је и реченица на српском безлична.

Уколико је у руској безличној реченици присутан детерминатор, у српском језику ће се користити лична, тј. двочлана реченица. Погледајмо пример:

\footnotetext{
${ }^{3} \mathrm{C}$ обзиром на то да је примера свега седамнаест, желели смо да сачувамо и евентуални хронолошки преглед анализираних реченица: ознака испред сваког примера означава редни број фише.
} 


\section{ф7}

[...] всегда по вечерам в его комнатку приходил Версилов; всегда приходил я, да и негде мне было и быть; [...].

Дост Подр ч3 г3 III
[...] у његову собу је стално увече долазио Версилов; увек сам ја долазио, а нисам ни имао где друго да будем;

Дост Д2 124

У примеру који смо навели руска безлична реченица је у прошлом времену, тако да је у саставу предиката и облик средњег рода копулативног глагола быть (было) који свакако треба разликовати од пунозначног глагола быть који се у овој реченици налази у инфинитиву. Посесор је у руском језику исказан дативом личне заменице првог лица, док је у српском језику изражен номинативом личне заменице $а$ и у функцији је граматичког субјекта. У овом примеру је преводилац уместо инфинитива употребио конструкцију $\partial a+$ презент.

\section{б) некуда}

У анализираном роману посведочен је само један пример безличне реченице са одричним заменичким прилогом за место некуда у функцији предиката:

$\phi 13$

Да ведь несчастному князю Николаю Ивановичу почти и некуда спастись теперь от всей этой интриги [...]

$$
\text { Дост Подр ч3 г9 I }
$$

Та несрећни кнез Николај Иванович скоро да нема куд сад да се склони од читаве ове сплетке $[\ldots]$.

Дост Д2 168

Руска безлична реченица је у садашњем времену тако да је предикат изражен заменичким прилогом за место некуда уз допуну глагола у инфинитиву. Субјекатски предикат је присутан и изражен је дативом једнине именице князь. У преводу је реченица двочлана са граматичким субјектом израженим номинативом једнине именице кнез и обликом трећег лица једнине презента глагола немати у функцији предиката уз прилог куд и конструкцијом да+презент (да се склони).

\section{в) неоткуда}

У анализираном роману није било примера безличних реченица са одричним заменичким прилогом за место неоткуда у функцији предиката. 


\section{г) некогда}

У анализираном роману посведочено је једанаест примера безличних реченица са одричним заменичким прилогом за време некогда у функцији предиката.

Веома су ретки примери безличних реченица са заменичким прилогом некогда без субјекатског детерминатора. У таквим случајевима ће и реченица у српском језику бити безлична. Навешћемо пример посведочен у истраживаном корпусу:

ф17

Опять повторяю: рассудить было

Опет понављам: није се имало кад некогда. размишљати.

Дост Подр ч3 г12 IV

Дост Д2 320

Руска безлична реченица је у наведеном примеру у прошлом времену што закључујемо на основу присуства безличног облика помоћног глагола быть (облик средњег рода было); инфинитив је у препозицији, а сам глагол је свршеног вида. Како субјекатски детерминатор није изражен нити га је могуће васпоставити из ширег контекста, у српском преводу налазимо такође безличну реченицу; руски инфинитив преведен је такође инфинитивом, али је употребљен глагол несвршеног вида.

Руске безличне реченице са заменичким прилогом за време некогда на српски језик се преводе на исти начин као и реченице са прилогом негде, тачније: у преводу се користи одговарајући лични или безлични облик глагола немати и заменички прилог за време кад(a), с тим што се уместо прилога као преводна варијанта може искористити и именица време у генитиву, као у следећем примеру:

$$
\text { ф4 }
$$

[...] и как я вас тогда принял, но теперь [мне] некогда [говорить] об этом, Татьяна Павловна не даст рассказать.

$$
\text { Дост Подр ч1 г6 IV }
$$

[...] и како сам вас тада примио, али [ја] сада немам времена да о томе говорим, Татјана Павловна ми неће дати да испричам.

Дост Д1 148

Код наведеног примера можемо приметити да је у руском језику било потребно на основу ширег контекста васпоставити субјекат посесивности и исказати га дативом, а на основу ширег контекста могуће је васпоставити и одговарајући инфинитив који је и преводилац препознао и на српски језик превео конструкцијом да+презент. У српском језику реченица је лична, дакле 
двочлана са изостављеним граматичким субјектом о којем информацију добијамо на основу првог лица једнине презента глагола немати, облика којим је изражен предикат.

Субјекат посесивности, тј. субјекатски детерминатор у руској безличној реченици може бити изостављен и када је инфинитив у препозицији а сама реченица у прошлом времену. Погледајмо пример ексцерпиран из анализираног корпуса:

$$
\text { ф5 }
$$

Но очень много думать об этом [мне] было некогда: у меня в голове сидел Крафт.

Дост Подр ч1 г9 I
Али [ja] нисам имао времена да много размишљам о томе: на уму ми је непрекидно био Крафт.

Дост Д1 195

У примеру који смо навели у руској безличној реченици васпостављен је субјекатски детерминатор исказан дативом личне заменице за прво лице, а информацију о томе налазимо у ширем контексту, тачније: у реченици која следи након безличне где је субјекат посесивности изражен генитивом једнине личне заменице за прво лице са предлогом $y$. И сада је у преводу уместо прилога кад употребљена именица време у генитиву једнине.

Једини руски одрични заменички прилог који може и самостално да врши функцију предиката, тј. који не захтева увек допуну у инфинитиву јесте управо прилог некогда. У анализираној грађи посведочене су и овакве безличне реченице:

$\phi 10$

А что, откажет она ему, как ты думаешь?

- Прощай, [мне] некогда, - оборвала Лиза, [...].
А хоће ли га она одбити, шта мислиш?

- Збогом, [ja] немам времена - прекиде Лиза разговор, [...].

Дост Д1 303

У српском језику у наведеном примеру као еквивалент руске безличне реченице појављује се двочлана реченица са изостављеним граматичким субјектом, а граматички објекат је уједно и посесум и изражен је генитивом једнине именице време.

Безлична реченица са предикатом израженим одричним заменичким прилогом некогда који нема допуну у инфинитиву може бити и зависна компонента зависно-сложене реченице: 
ф11

[...] он совсем бы выровнялся и стал бы счастлив. Жаль, что [мне] некогда... да проедем вместе немного, я бы тебе сообщил кое-что...

$$
\text { Дост Подр ч2 г3 IV }
$$

[...] постао би потпуно уравнотежен и срећан. Штета што немам времена... али хајде да те мало повезем, испричаћу ти понешто.

Субјекат посесивности у наведеном примеру постоји, али је неизражен, што је случај и код руске и код српске реченице, те се, као и код ранијих примера, васпостављање изостављеног реченичног члана врши на основу ширег контекста или ванјезичке ситуације. Дакле, пошто посесор у структури ове руске безличне реченице ипак постоји, у српском језику ће реченица бити двочлана, док је предикат изражен обликом првог лица једнине садашњег времена глагола немати, а објекат је, као и у претходном примеру, изражен генитивом једнине именице време.

У анализираном роману посведочени су и примери безличних реченица са заменичким прилогом некогда и израженим субјекатским детерминатором, без допуне у инфинитиву; најпре ћемо навести реченицу у садашњем а затим у прошлом времену:

$$
\text { ф8 }
$$

- Я, князь, - начал было я...

- Мне, право, некогда, Аркадий Макарович, я сейчас еду.

- Одну минутку, князь, мне очень важное; [...].

Дост Подр ч2 г2 III
Странный мальчик повернулся и вышел. Мне только было некогда, но я положил непременно разыскать его вскорости, только что улажу наши дела.

$$
\text { Дост Подр ч3 г10 II }
$$

- Ја, кнеже... - почех.

- Заиста немам кад, Аркадије Макаровичу, одмах морам да идем.

- Један тренутак, кнеже, ствар је веома важна; [...].

Дост Д1 283

Чудни дечак се окрену и изађе. Тада нисам имао времена, али сам наумио да га обавезно ускоро нађем, чим посвршавам наше послове.

Дост Д2 266

Субјекатски детерминатор може доћи у постпозицији, тј. налазити се после заменичког прилога некогда, као у следећем примеру: 


\section{$\phi 15$}

O! я не стану описывать мои чувства, да и некогда мне [их описывать], но отмечу лишь одно: [...].

$$
\text { Дост Подр ч3 г12 II }
$$

O! Нећу описивати шта сам осећао, а и времена немам [да их описујем], али истичем једну ствар: $[. .$.$] .$

Дост Д2 313

У наведеном примеру је у руској безличној реченици у садашњем времену изостављен инфинитив али и његова допуна; у преводу је реченица двочлана са изостављеним граматичким субјектом који се може васпоставити на основу предиката ([ja] немам). Уместо прилога кад употребљена је именица време у генитиву једнине.

Када се ради о руским безличним реченицама са прилогом некогда у функцији предиката, уколико је реченица у прошлом времену, субјекатски детерминатор изражен дативом и заменички прилог могу мењати места ([мне некогда : некогда мне] было), тј. распоред реченичних чланова може бити различит, али се те разлике углавном не одражавају на превод, о чему сведоче следећа два примера:

ф3

Да, я мечтал изо всех сил и до того, что мне некогда было разговаривать; $[\ldots]$.

$$
\text { Дост Подр ч1 г5 III }
$$

$\phi 9$

Только некогда мне было вникать тогда ни в какие интриги, [...].

Дост Подр ч2 г3 II
Јесте, маштао сам свим бићем и толико да нисам имао кад да разговарам; [...].

Дост Д1 108
Само што тада нисам имао кад да се удубљујем ни у какве сплетке, [...].

Оба наведена примера за преводне еквиваленте имају двочлане реченице са изостављеним граматичким субјектом чији су предикати исказани перфектом глагола немати (нисам имао) уз прилог кад; оба руска инфинитива су несвршеног вида и преведена су конструкцијама $\partial a+$ пезент глагола који су такође несвршеног вида.

Навешћемо и једини посведочени пример руске безличне реченице са заменичким прилогом некогда у којој би посесор, да је изражен, требало да има облик датива личне заменице $\mathrm{mbl}$ : 
$\phi 16$

Уж конечно, в этом сумасшедшем известии даже с первого взгляда заключалось нечто несообразное, но обдумывать [нам] было некогда, потому что в сущности все было ужасно правдоподобно.

Дост Подр ч3 г12 III
Наравно, у тој лудој вести чак је и на први поглед било нечег противречног, али нисмо имали времена да размишљамо, јер је, у суштини, све било јако уверљиво.

Дост Д2 317

Инфинитив је у наведеном примеру присутан и то у препозицији у односу на заменички прилог. У српској реченици је посесор такође изостављен, али се може васпоставити на основу предиката.

\section{д) незачем}

У анализираном роману посведочено је свега два примера безличних реченица са одричним заменичким прилогом незачем у функцији предиката.

Субјекат посесивности је у следећем примеру изостављен, а васпоставља се на основу ширег контекста; предикат је у руској реченици изражен заменичким прилогом незачем и инфинитивом, док у српском преводу налазимо израз нема потребе и конструкцију да+презент за руски инфинитив:

$\phi 12$

От холода еще сильнее будут гореть, стоит только рукой достать одно березовое полено... да и незачем совсем доставать полено: [...].

Дост Подр ч2 г9 I

На хладноћи ће још боље горети, треба само да дохватим једну брезову цепаницу... а уопште нема потребе ни да дохватам цепаницу: [...].

У руским безличним реченицама са одричним заменичким прилогом незачем инфинитив такође може бити изостављен, тако да би реченица формално могла имати само предикат исказан прилогом: 


\section{ф6}

Вам ужасно хочется, чтоб я сходил к какой-нибудь здешней Жозефине и пришел, вам донести. Незачем; я и сам еще тринадцати лет видел женскую наготу, всю; с тех пор и почувствовал омерзение..

Дост Подр ч1 г2 III
Ви бисте страшно волели да ја одем код неке овдашње Жозефине и дођем да вам испричам. Нема потребе; и сам сам од тринаест година видео женску голотињу, и то скроз; отада и осећам одвратност. Дост Д1 40

У наведеном примеру посесор није изражен, али би могао бити исказан дативом личне заменице за друго лице $6 ы$ а васпостављен би био на основу ширег контекста. У преводу налазимо исто што и у претходном примеру - израз Нема потребе.

\section{ИЗВОРИ}

Дост Подр - Ф. М. Достоевский. Подросток.

$<$ http://az.lib.ru/d/dostoewskij_f_m/text_0090.shtml> 2.1.2018.

Дост Д1 - Ф. М. Достојевски. Дечко. књ. 1. Превели Милена и Радмило Маројевић. Београд: Српски фонд словенске писмености и словенских култура. Горњи Милановац: Дечје новине. Москва: Радуга. 1992. (штампано у Москви).

Дост Д2 - Ф. М. Достојевски. Дечко. књ. 2. Превели Милена и Радмило Маројевић. Београд: Српски фонд словенске писмености и словенских култура. Горњи Милановац: Дечје новине. Москва: Радуга. 1992. (штампано у Москви).

\section{ЛИТЕРАТУРА}

Бабајцева 2015: В. В. Бабайцева, Синтаксис русского языка. Монография. Москва: Флинта, Наука.

Вељковић 2012: М. Вељковић, Руске посесивне реченице са глаголом иметь $u$ њихови српски еквиваленти (сажетак на српском језику, резиме на руском језику), Универзитет у Нишу, Научни скуп Наука и савремени универзитет, 10-11. новембар 2011. Књига резимеа, Ниш, 2011. с. 160-161; Филологија и универзитет, Тематски зборник радова, Научни скуп Наука и савремени универзитет 1, 
Универзитет у Нишу, Филозофски факултет, Издавачки центар, Ниш, 2012. с. 914-931.

Вељковић 2013: М. Вељковић, Руске посесивне реченице и њихови српски еквиваленти (Логичко-семантички и формалнограматички аспекm), Научни диалози, Сборник посветен на 10-годишнината от научното партньорство между Филологическия и Философския факултет на Университетите във Велико Тьрново и Ниш, Филологически факултет (Велико Тьрново), Философски факултет (Ниш), Велико Тьрново, 2012, с. 53-74.

Вељковић 2017: М. Вељковић, Руски одрични заменички прилози у функцији предиката и њихови српски еквиваленти, у: Наука и савремени универзитет 7, Књига резимеа, Ниш: Филозофски факултет, 176-177.

Колмакова 1999: В. В. Колмакова, Отрицательные местоимения с ни- $u$ не-, их статус в системе частей речи. <http://www.dissercat.com/ content/otritsatelnye-mestoimeniya-s-ni-i-ne-ikh-status-v-sistemechastei-rechi\#ixzz53bSgAQhX> 2.1.2018.

Маројевић 2001': Радмило Мароевич. Русская грамматика: Сопоставительная грамматика русского и сербского языков с историческими комментариями. Том І. Типология. Фонология. Морфология имени. Москва - Белград, 2001.

Маројевић 2001²: Радмило Мароевич. Русская грамматика: Сопоставительная грамматика русского и сербского языков с историческими комментариями. Том II. Морфология глагола. Синтаксис. Теория перевода. Москва - Белград, 2001.

PГ2 2005: Русская грамматика. Том II. Российская академия наук. Институт русского языка им. В. В. Виноградова. Москва, 2005 (1980).

Скобљикова 2006: Е. С. Скобликова. Современный русский язык. Синтаксис простого предложения (теоретический курс). Учебное пособие. Третье издание, исправленное и дополненное. Москва: Флинта, Наука.

Чурикова 2003: С.М. Чурикова. Двойное отрицание в предложениях типа Поговорить не о чем // II Международные Бодуэновские чтения: Казанская лингвистическая школа: традиции и современность (Казань, 11-13 декабря 2003 г.): Труды и материалы: В 2 т. / Под общ. ред. К.Р. Галиуллина, Г.А. Николаева.- Казань: Изд-во Казан. ун-та, 2003.- Т. 2. - С. 48-49. 


\section{РУССКИЕ ОТРИЦАТЕЛЬНЫЕ МЕСТОИМЕНЫЕ НАРЕЧИЯ В ФУНКЦИИ СКАЗУЕМОГО И ИХ СЕРБСКИЕ ЭКВИВАЛЕНТЫ}

\section{Резюме}

В русском языке существуют безличные предложения, сказуемое которых выражается отрицательными местоименными наречиями (негде, некуда, некогда, незачем), чаще всего в сочетании с инфинитивом глагола (хотя инфинитив иногда опускается). Эти русские безличные предложения переводят на сербский язык безличными или двусоставными предложениями, в зависимости от наличия или отсутствия в предложении субъекта, т.е. косвенного дополнения со значением производителя действия. Сказуемое сербских предложений чаще всего выражается соответствующей личной или безличной формой глагола немати в сочетании с наречиями времени, места, причины. Это и является предметом данного исследования, результаты которого представлены в настоящей статье.

Ключевые слова: отрицательное местоименное наречие, сказуемое, безличность, немати.

Маја 3. Вељковић 